\title{
Phenological behaviour of gobhi sarson (Brassica napus L.) and thermal indices as influenced by drip irrigation and fertigation schedules under semi-arid subtropical conditions of Punjab
}

\author{
RAJNI SHARMA ${ }^{1 *}$, DIVYA S. KUMAR ${ }^{1}$, A.S. BRAR ${ }^{1}$ and SOMPAL SINGH ${ }^{2}$ \\ ${ }^{1}$ Department of Agronomy, ${ }^{2}$ Department of Climate Change and Agricultural Meteorology \\ Punjab Agricultural University, Ludhiana, India \\ Corresponding author email : rajni-sharma@pau.edu
}

\begin{abstract}
A field experiment was conducted during rabi 2016-17 and 2017-18 at the Research Farm of Department of Agronomy, Punjab Agricultural University, Ludhiana, to study the phenological behaviour of gobhi sarson (Brassica napus L.) and thermal indices as influenced by drip irrigation (60, 80 and 100\% of cumulative pan-evaporation, CPE) and fertigation schedules $(60,80$ and $100 \%$ recommended dose of fertilizers, RDF) in comparison with conventional flood irrigation and manual application of fertilizers i.e. absolute control. The pooled data revealed that Brassica irrigated through drip at $100 \%$ of CPE took maximum number of days to attain $50 \%$ flowering, $50 \%$ siliqua formation and physiological maturity, followed by 80 and $60 \%$ of CPE. Higher fertigation levels also delayed the number of days taken to attain various phenological stages. Maximum seed yield was observed at $100 \%$ of CPE with $100 \%$ RDF which was statistically at par with $100 \%$ of CPE with $80 \%$ RDF and $80 \%$ of CPE with 80 or $100 \%$ RDF, but significantly higher than absolute control. Maximum accumulation of heat units along with heat use efficiency $\left(1.49 \mathrm{~kg} \mathrm{grains}^{-1}\right.$ ${ }^{\circ} \mathrm{C}$ day hour ${ }^{-1}$ ) was also obtained at $100 \%$ of CPE with $100 \%$ RDF.
\end{abstract}

Key words: Gobhi sarson, drip irrigation, fertigation, phenology, thermal indices

Temperature plays a vital role in growth and development of crop plants by regulating their physiological, chemical and biological processes. Each plant requires a certain specific amount of heat units to attain a developmental stage or to move from one developmental stage to another (Kumar et al., 2014). Accumulated heat units or GDD (a thermal time concept) is the amount of heat energy accumulated by crop plants over a period of time and is based on the principle that actual time required by crop plants to attain a particular phenological stage is directly related to temperature ranged between base temperature (below which no growth takes place) and optimum temperature. Heat unit concept was generally applied to correlate phenological development in crops to predict crop maturity dates (Kiran and Chimmad, 2018). Consequently, agro-climatic models based on thermal indices such as growing degree days (GDD) which relate temperature to crop growth and dry matter production can effectively be used for prediction of growth and yield based on weather parameters (Rao et al., 1999).
Gobhi sarson (Brassica napus L.), being a temperate crop, grows well under temperature ranging from $15-25^{\circ} \mathrm{C}$. The germination is quick at $27^{\circ} \mathrm{C}$, but further growth and development needs a cool temperature between $15-20^{\circ} \mathrm{C}$ and at maturity, a high temperature up to $28-30^{\circ} \mathrm{C}$ is desired (Joshi, 2015). Unlike other crops, it also requires accumulation of definite amount of heat units to achieve various phonological stages viz. flowering, siliqua initiation and crop maturity. Although accumulation of degree days for each development stage is relatively constant and is independent of cultural practices, but irrigation along with fertigation may modify it significantly. Under irrigated conditions, maturity of Brassica crop gets exaggerated due to frequent irrigation and fertigation schedules even at lower doses. Besides this, drip irrigation and fertigation reduces the wastage of water and chemical fertilizers, optimizes the nutrient use by applying them at critical stages and at proper place and time, which finally increase water and nutrient use efficiency (Sandal and Kapoor, 2015). Therefore, it becomes imperative to have knowledge of exact duration 

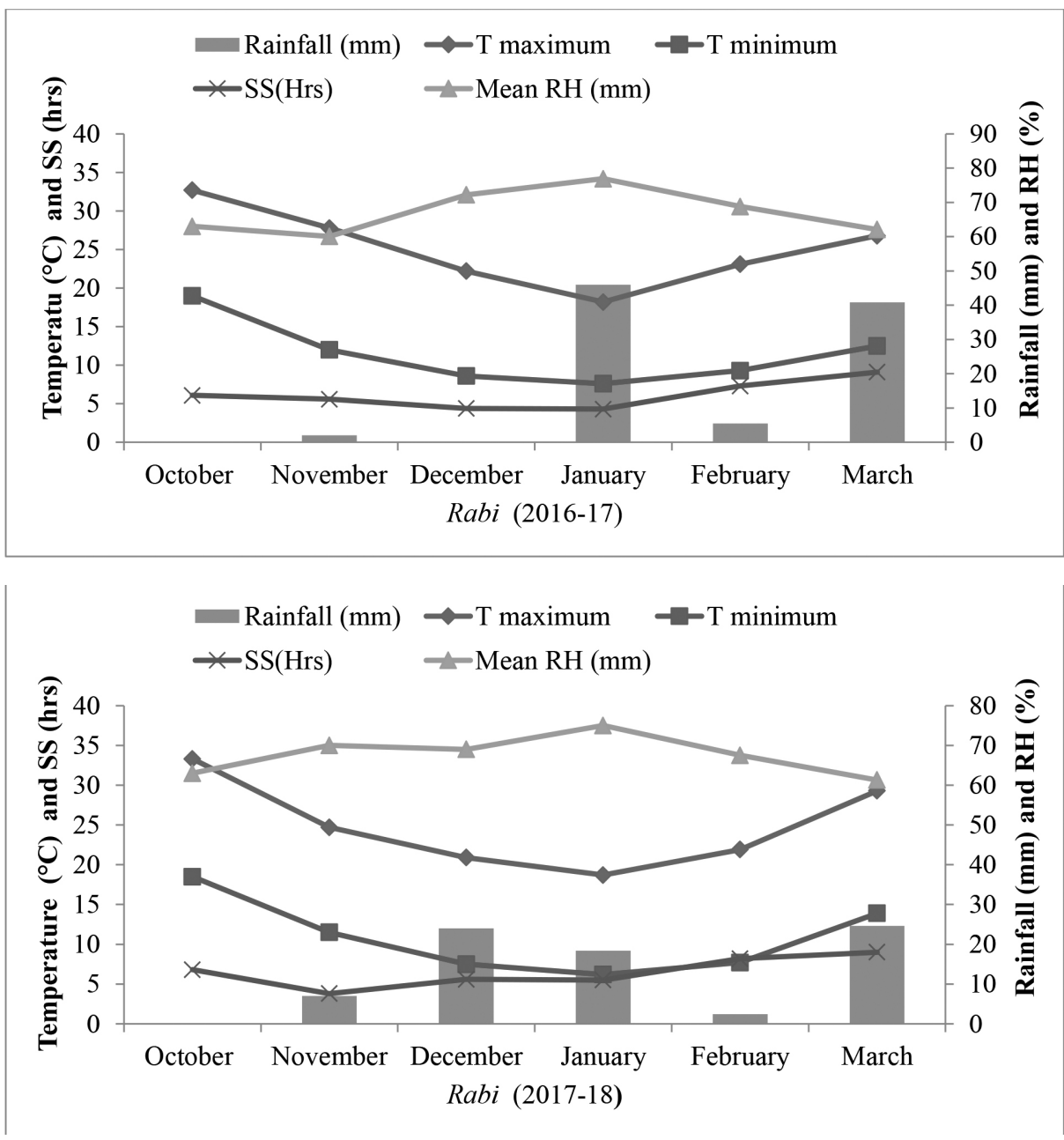

Fig. 1: Meteorological data during crop growing seasons (Rabi 2016-17 and 2017-18)

of phenological stages and accumulation of thermal indices under drip irrigation and fertigation and their impact on crop maturity and yield. Keeping this in view, the present investigation was carried out to study the effect of drip irrigation and fertigation schedules on phenology of gobhi sarson and thermal indices under semi-arid, subtropical climate of Punjab, India.

\section{MATERIAL AND METHODS}

The field experiment was conducted at the Research Farm of Department of Agronomy, Punjab Agricultural University, Ludhiana situated at $30^{\circ} 54^{\prime} \mathrm{N}$ latitude and $75^{\circ} 48^{\prime} \mathrm{E}$ longitude with an elevation of 247 $\mathrm{m}$ above mean sea level during the rabi seasons of 201617 and 2017-18. This part of Punjab features a semi-arid, sub-tropical climate with cold winters and hot summers. The mean monthly maximum temperature ranged between 18.2-32.7 and $18.7-33.3^{\circ} \mathrm{C}$, mean monthly minimum temperature $7.6-19.0$ and $6.2-18.5^{\circ} \mathrm{C}$, whereas mean relative humidity remained $60.1-76.9$ and $61.3-75.0 \%$ during 2016-17 and 2017-18, respectively (Fig. 1). A total rainfall of 94.0 and $76.4 \mathrm{~mm}$ was received during both the years, respectively.

The soil of the experimental field was loamy sand in texture having $1.58 \mathrm{~g} \mathrm{~cm}^{-3}$ average bulk density of soil profile from $0-30 \mathrm{~cm}$ depth. The experiment was conducted in randomized complete block design keeping combination of three irrigation levels at 60,80 and $100 \%$ of cumulative pan evapo-transpiration (CPE) and three fertigation levels with 60,80 and $100 \%$ recommended dose of fertilizers (RDF) comprising of nine treatments under drip irrigation along with one conventional flood irrigation and manual application of fertilizers (absolute control). The gross size of the experimental plot was 5.6 $\mathrm{m} \times 3 \mathrm{~m}$ and in each plot, six rows of gobhi sarson L. 
Table 1: Effect of drip irrigation and fertigation schedules on phenological stages of gobhi sarson var. GSC-7 (pooled data)

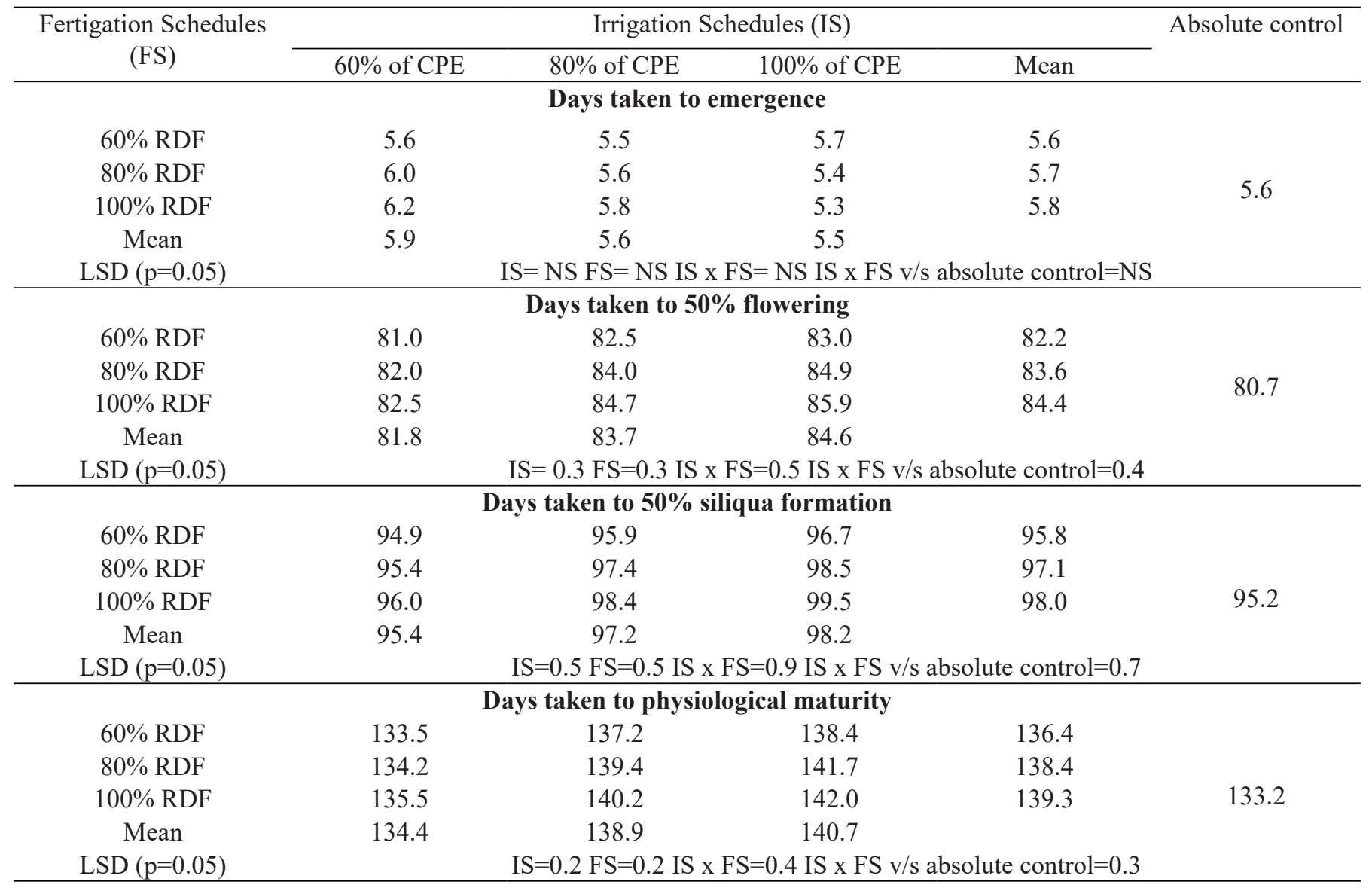

(variety GSC-7) were sown at the recommended seed rate of $3.75 \mathrm{~kg} \mathrm{ha}^{-1}$ with hand drill in rows $45 \mathrm{~cm}$ apart. Irrigation schedules were started at one month after sowing and thereafter applied at a fixed interval of six days. The fertigation schedules $\left(150 \mathrm{~kg} \mathrm{~N}\right.$ and $30 \mathrm{~kg} \mathrm{P}_{2} \mathrm{O}_{5}$ $\mathrm{ha}^{-1}$ ) were started after 15 days of sowing and completed in 10 splits with an interval of 6 days. In flood irrigated plot, half $\mathrm{N}$ and full $\mathrm{P}_{2} \mathrm{O}_{5}$ was applied before sowing and the remaining half $\mathrm{N}$ was applied with first irrigation.

Observations on important phenophases viz. emergence, $50 \%$ flowering, $50 \%$ siliqua formation and physiological maturity were recorded. The data on meteorological parameters such as rainfall, relative humidity, maximum and minimum temperature, bright sunshine hours and day length were obtained from Agro-meteorological Observatory, Punjab Agricultural University, Ludhiana (Fig. 1).

\section{Heat use}

The growing degree days (GDD) were calculated using the following expressions.

$\mathrm{GDD}=\left(\mathrm{T}_{\max }+\mathrm{T}_{\text {min }}\right) / 2-\mathrm{T}_{\text {base }}$

Where, $\mathrm{T}_{\max }=$ Daily maximum temperature $\left({ }^{\circ} \mathrm{C}\right) ; \mathrm{T}_{\min }=$ Daily minimum temperature $\left({ }^{\circ} \mathrm{C}\right) ; \mathrm{T}_{\text {base }}=$ Base temperature for gobhi sarson was taken as $5^{\circ} \mathrm{C}$.

\section{Heat use efficiency (HUE)}

HUE $\left(\mathrm{kg}\right.$ grains ha-1 o $\left.\mathrm{C} \mathrm{day}^{-1}\right)=$ Grain yield $\left(\mathrm{kg} \mathrm{ha}^{-1}\right) /$ AGDD $\left({ }^{\circ} \mathrm{C}\right.$ day $\left.^{-1}\right)$

Where, AGDD $\left({ }^{\circ} \mathrm{C}\right.$ day $\left.^{-1}\right)=$ Accumulated growing degree days

\section{Statistical analysis}

Analysis of variance was done to investigate the effect of drip irrigation and fertigation schedules on various recoded parameters of gobhi sarson and their interaction. The variance was analyzed using SAS software 9.3, SAS 
institute Ltd, USA and the difference between means was compared with Fisher's least significant difference (LSD) test at $5 \%$ probability level.

\section{RESULTS AND DISCUSSION}

\section{Crop phenology}

Periodic occurrence of different developmental stages in the life cycle of a crop plant in relation to environmental conditions is known as crop phenology. Effect of drip irrigation and fertigation schedules were found to be significant for all the phenological stages except for number of days taken to emergence as none of the treatment was applied to the field as well as to the seeds at the time of sowing (Table 1). The Brassica crop drip irrigated at $100 \%$ of CPE took the maximum number of days to attain $50 \%$ flowering ( 85 days), $50 \%$ siliqua formation (98 days) and physiological maturity (141 days), which was significantly higher than 80 and $60 \%$ of CPE. Higher fertigation levels also delayed the number of days taken to attain various phenological stages. Scheduling at $100 \%$ RDF took maximum time to achieve $50 \%$ flowering, $50 \%$ siliqua formation and physiological maturity which were significantly higher than 80 and $60 \%$ RDF. Crop raised at lower irrigation levels along with lower doses of fertigation might have challenged by moisture and nutrient stress, therefore to mitigate the stress led to early flowering, which further facilitated earlier siliqua formation and physiological maturity. Similarly, Kingra et al., (2011) documented higher number of days taken by crop to attain physiological maturity under increased frequency of irrigation in wheat. Moreover, nitrogen favoured late completion of vegetative phase of the plant, therefore, late mobilization of assimilates to the sink, facilitated higher number of days taken to attain physiological maturity with increased nitrogen levels. Likewise, Kaur et al., (2017) revealed that higher doses of nitrogen resulted in delayed number of days taken to $50 \%$ flowering and maturity in gobhi sarson. Nevertheless, delayed maturity was also reported by Ahmad et al. (2006) with increasing nitrogen rate progressively.

Interactions between drip irrigation and fertigation schedules were also found significant for all the phenological stages (Table 1). All treatment combinations acquired significantly more time to attain
$50 \%$ flowering, 50\% siliqua formation and physiological maturity as compared to absolute control except for $60 \%$ of CPE with $60 \%$ RDF which was statistically at par with absolute control for days taken to $50 \%$ flowering and physiological maturity. The crop irrigated with flood method might have undergone moisture stress, as water is available at one growth stage might lead to moisture stress at other stage. Thus, the crop irrigated by flood method resulted in early flowering to mitigate that stress.

\section{Heat use}

Drip irrigation and fertigation schedules significantly influenced accumulation of heat units to attain physiological maturity in Brassica (Table 2). Drip irrigation at $100 \%$ of $\mathrm{CPE}$ accumulated significantly higher heat units, $\left(1579^{\circ} \mathrm{C}\right.$ day $)$ which were statistically more than 80 and $60 \%$ of CPE. Thus, decreased levels of drip irrigation from 100 to $60 \%$ of CPE resulted in decreased accumulation of thermal indices to attain maturity. Similar results were documented by Dar et al., (2018) in wheat. The reduction in accumulation of heat units was due to reduction in number of days taken to attain physiological maturity under water stress conditions (Brar et al., 2016). Correspondingly, the requirement of heat units was higher for $100 \%$ RDF than 80 and $60 \%$, to attain physiological maturity. This could be the fact that higher nitrogen level increased vegetative growth and delays maturity. Interaction between drip irrigation and fertigation schedules was also found to be significant. Among treatment combinations, drip irrigation at $100 \%$ of CPE with 100\% RDF accumulated significantly higher heat units to attain physiological maturity, which was statistically similar with $100 \%$ of CPE and $80 \%$ RDF but significantly higher than rest of the treatment combinations. All drip irrigation and fertigation treatments significantly require higher accumulated thermal indices to attain maturity over absolute control except $60 \%$ of CPE with $60 \%$ RDF, which was statistically similar with absolute control.

\section{Seed yield}

Gobhi sarson cv. GSC-7 responded significantly to both irrigation and fertigation treatments. The results pertaining to the seed yield under drip irrigation and fertigation scheduling (Table 2) revealed that drip 
Table 2: Effect of drip irrigation and fertigation schedules on heat use efficiency of gobhi sarson var. GSC-7 (pooled data)

\begin{tabular}{|c|c|c|c|c|c|}
\hline \multirow{2}{*}{$\begin{array}{l}\text { Fertigation schedules } \\
\qquad \text { (FS) }\end{array}$} & \multicolumn{4}{|c|}{ Irrigation schedules (IS) } & \multirow[t]{2}{*}{ Absolute control } \\
\hline & $60 \%$ of $\mathrm{CPE}$ & $80 \%$ of $\mathrm{CPE}$ & $100 \%$ of CPE & Mean & \\
\hline \multicolumn{6}{|c|}{ Heat use $\left({ }^{\circ} \mathrm{C}\right.$ day $)$} \\
\hline $60 \% \mathrm{RDF}$ & 1450 & 1504 & 1537 & 1497 & \\
\hline $80 \% \mathrm{RDF}$ & 1465 & 1555 & 1595 & 1538 & 1443 \\
\hline $100 \% \mathrm{RDF}$ & 1482 & 1567 & 1606 & 1551 & \\
\hline Mean & 1466 & 1542 & 1579 & & \\
\hline $\operatorname{LSD}(p=0.05)$ & & $2.7 \mathrm{FS}=12.7 \mathrm{I}$ & $21.9 \mathrm{ISxFS} \mathrm{v/s}$ & control & \\
\hline \multicolumn{6}{|c|}{ Seed yield $\left(\mathrm{kg} \mathrm{ha}^{-1}\right)$} \\
\hline $60 \% \mathrm{RDF}$ & 1710 & 1930 & 2000 & 1880 & \multirow{4}{*}{1830} \\
\hline $80 \% \mathrm{RDF}$ & 1890 & 2250 & 2330 & 2157 & \\
\hline $100 \% \mathrm{RDF}$ & 1940 & 2310 & 2390 & 2213 & \\
\hline Mean & 1847 & 2163 & 2240 & & \\
\hline \multirow{2}{*}{\multicolumn{6}{|c|}{$\begin{array}{l}\mathrm{IS}=86.9 \mathrm{FS}=86.9 \mathrm{ISxFS}=150.5 \mathrm{ISxFS} \text { v/s absolute control= } 112.1 \\
\text { Heat use efficiency }(\mathbf{H U E})\left(\mathbf{k g} \text { grains } \mathbf{~ h a}^{-\mathbf{1 0}} \mathbf{C} \text { day }^{-1}\right)\end{array}$}} \\
\hline & & & & & \\
\hline $60 \% \mathrm{RDF}$ & 1.18 & 1.28 & 1.30 & 1.25 & \multirow{4}{*}{1.27} \\
\hline $80 \% \mathrm{RDF}$ & 1.29 & 1.45 & 1.46 & 1.40 & \\
\hline $100 \% \mathrm{RDF}$ & 1.31 & 1.47 & 1.49 & 1.42 & \\
\hline Mean & 1.26 & 1.40 & 1.42 & & \\
\hline
\end{tabular}

Table 3: Correlation and regression coefficients between accumulated growing degree days (AGDD) and seed yield of gobhi sarson at different phenological stages

\begin{tabular}{cccc}
\hline Phenological stages & Correlation $(\mathrm{r})$ & Regression $(\mathrm{b})$ & Coefficient of determination $\left(\mathrm{r}^{2}\right)$ \\
\hline $50 \%$ flowering & $0.95^{*}$ & $13.25^{*}$ & 0.90 \\
$50 \%$ siliqua formation & $0.95^{*}$ & $15.79^{*}$ & 0.91 \\
Physiological maturity & $0.96^{*}$ & $3.85^{*}$ & 0.92 \\
\hline
\end{tabular}

*Significant at 5\% level

irrigation at $100 \%$ of CPE recorded maximum seed yield (2240 $\mathrm{kg} \mathrm{ha}^{-1}$ ), which was statistically at par with $80 \%$ of CPE (2163 kg ha-1) but $21.3 \%$ higher than $60 \%$ of CPE (1847 $\left.\mathrm{kg} \mathrm{ha}^{-1}\right)$ in pooled data. The crop irrigated through drip at $100 \%$ of CPE meant that the crop was exposed to greater availability of moisture at all the growth stages, whereas $60 \%$ of CPE might have caused moisture stress. Therefore, there is drastic reduction in seed yield at $60 \%$ of CPE as compared to irrigation at 100 and $80 \%$ of CPE. In case of fertigation, $100 \%$ RDF resulted in maximum seed yield of $2213.3 \mathrm{~kg} \mathrm{ha}^{-1}$, which was statistically similar with $80 \%$ RDF (2157 $\mathrm{kg} \mathrm{ha}^{-1}$ ) but $17.7 \%$ higher than $60 \%$ RDF (1880 $\left.\mathrm{kg} \mathrm{ha}^{-1}\right)$. The increase in seed yield with increase in fertilizer doses has also been reported by Rathod et al., (2014). Among treatment combinations, maximum yield was produced under irrigation at $100 \%$ of CPE with fertigation at 100\% RDF which was $30.6 \%$ higher than absolute control. All treatment combinations recorded significantly higher seed yield as compared to absolute control except $60 \%$ of CPE and $60 \%$ RDF. The results were also endorsed by the findings of Sinha et al., (2017) and Sahoo et al., (2018).

\section{Heat use efficiency (HUE)}

Heat use efficiency is an indicator of number of grains produced per unit accumulated heat unit. Maximum HUE was recorded when crop was drip irrigated at $100 \%$ of CPE (1.42 kg grains ha- ${ }^{\circ} \mathrm{C}$ day $\left.^{-1}\right)$, followed by $80 \%$ $\left(1.40 \mathrm{~kg}\right.$ grains $\mathrm{ha}^{-1}{ }^{\circ} \mathrm{C}$ day $^{-1}$ ) and $60 \%$ (1.26 kg grains $\mathrm{ha}^{-1}{ }^{\circ} \mathrm{C}$ day $\left.^{-1}\right)$. Among fertigation schedules, maximum HUE was observed at $100 \%$ RDF (1.42 kg grains ha-1 ${ }^{\circ} \mathrm{C}$ day $\left.^{-1}\right)$ and minimum at $60 \%\left(1.25 \mathrm{~kg}\right.$ grains $\mathrm{ha}^{-1}{ }^{\circ} \mathrm{C}$ day $\left.^{-1}\right)$. In case of drip-fertigation levels, maximum HUE (1.49 $\mathrm{kg}$ grains $\mathrm{ha}^{-1}{ }^{\circ} \mathrm{C}$ day $^{-1}$ ), was obtained at $100 \%$ of CPE with $100 \%$ RDF and minimum at $60 \%$ of CPE with $60 \%$ RDF followed by absolute control. This could be the fact that lower levels of nitrogen and irrigation schedules facilitates early maturity and minimum accumulation of 
heat units as compared to higher levels. Dar et al., (2018) also reported decreased HUE with increased moisture deficit from FC15 to FC45 (depletion from field capacity) in wheat. The reduction in HUE with increase in moisture stress may be attributed to the reduction in yield under water stress conditions (Table 2).

\section{Correlation and regression analysis}

Simple correlation (r), regression (b) and coefficient of determination $\left(\mathrm{r}^{2}\right)$ among various parameters of Brassica revealed significant positive correlation of AGDD at 50\% flowering stage with seed yield indicating the influence of temperature on Brassica yield (Table 3). Data further indicated that with each unit increased in AGDD at 50\% flowering stage, seed yield increased by 13.25 units. AGDD at 50\% flowering accounted for more than $90.0 \%$ variation in seed yield. Likewise, AGDD at $50 \%$ siliqua formation and physiological maturity accounted for 90.5 and $92.0 \%$ variation in seed yield, respectively. The accumulation of GDD during 50\% siliqua formation and physiological maturity was found to be significantly and positively correlated with seed yield showing an increase of 15.79 and 3.85 units of seed yield with each unit increase in AGDD during both the stages, respectively.

\section{CONCLUSION}

To conclude this study, it has been observed that gobhi sarson cv. GSC-7 irrigated through drip at $100 \%$ of CPE with $100 \%$ RDF had taken maximum number of days to attain $50 \%$ flowering, 50\% siliqua formation and physiological maturity. Higher levels of drip irrigation and fertigation schedule also increased the duration and amount of accumulated heat units, seed yield and heat use efficiency in all the treatments as compared to absolute control (flood irrigation and manual application of fertilizers) except $60 \%$ of CPE with $60 \%$ RDF. Further, it can be determined that treatment combination $80 \%$ of CPE with $80 \%$ RDF was found most efficient in terms of early maturity and statistically similar seed yield in contrast to $100 \%$ of CPE with $100 \%$ RDF.

Conflict of Interest Statement: The author(s) declare(s) that there is no conflict of interest.
Disclaimer: The contents, opinions, and views expressed in the research article published in the Journal of Agrometeorology are the views of the authors and do not necessarily reflect the views of the organizations they belong to.

Publisher's Note: The periodical remains neutral with regard to jurisdictional claims in published maps and institutional affiliations.

\section{REFERENCES}

Ahmad, G., Inamullah,J.A. and Arif, M. (2006). Phenology and physiology of canola as affected by nitrogen and sulfur fertilization. J. Agron., 5: 555-562.

Brar, H.S., Vashist, K.K. and Bedi, S. (2016). Phenology and yield of spring maize (Zea mays L.) underdifferent drip irrigation regimes and planting methods. J. Agric. Sci. Tech., 18: 831843.

Dar, E.A., Brar, A.S. and Yousuf, A. (2018) Growing degree days and heat use efficiency of wheat as influenced by thermal and moisture regimes. $J$. Agrometeorol., 20(2): 168-170.

Joshi, M. (2015) Rapeseed and Mustard (Brassica spp.) In: Textbook of field crops. pp. 339-350, PHI Learning Pvt. Ltd, Delhi.

Kaur, M., Sardana, V. and Sharma, P. (2017). Performance of canola oilseed rape (Brassica napus), Ethiopian mustard (Brassica carinata) and Indian rape (Brassica rapa) in the intercropping system. Indian J. Agron., 62: 211-214.

Kingra, P.K., Mahey, R.K, Gill, K.K. and Singh, S.P. (2011). Thermal requirements and heat use efficiency of wheat under different irrigation levels. Indian J. Ecol., 38(2): 228-233.

Kiran, B.O. and Chimmad, V.P. (2018) Correlation studies on effect of temperature regimes on phenology, growing degree days, heat use efficiency and seed yield in chickpea (Cicer arietinum L.) genotypes. Int. J. Pure App. Biosci., 66(2): 248-252. 
Kumar, N., Kumar, S., Nain, A.S. and Roy, S. (2014). Thermal indices in relation to crop phenology of wheat (Triticum aestivum L.) and urd (Vigna mungo L. Hepper) at Tarai region of Uttarakhand. Mausam, 65(2): 215-218.

Rao, V.U.M., Singh, D. and Singh, R. (1999). Heat use efficiency of winter crops in Haryana. $J$. Agrometeorol., 1, 143- 148.

Rathod, S. S., Shekhawat, K., Premi, O. P., Kandpal, B. K. and Chauhan, J. S. (2014). Comparative effect of irrigation system and nitrogen fertigation on growth, productivity and water use efficiency of Indian mustard (Brassica juncea) under semi arid conditions of Rajasthan. Indian J. Agron., 59: 112-114.
Sahoo, P., Brar, A.S., Sharma, S. (2018). Effect of methods of irrigation and sulphur nutrition on seed yield, economic and bio-physical water productivity of two sunflower (Helianthus annuus L.) hybrids. Agric. Water Manage., 206: 158-164.

Sandal, S.K. and Kapoor, R. (2015) Fertigation technology for enhancing nutrient use and crop productivity: An overview. Himachal J. Agric. Res., 41(2): 114-121.

Sinha, I., Buttar, G. S., Brar, A. S. (2017). Drip irrigation and fertigation improve economics, water and energy productivity of spring sunflower (Helianthus annuus L.) in Indian Punjab. Agric. Water Manage., 185: 58-64. 